\title{
PHARMACY PRACTICE EXPERIENTIAL PROGRAMS IN THE CONTEXT OF CLINICAL EDUCATION
}

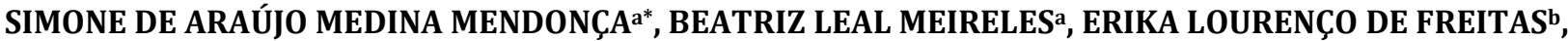 \\ DJENANE RAMALHO DE OLIVEIRA ${ }^{a}$
}

\author{
aSocial Pharmacy Department, College of Pharmacy, Federal University of Minas Gerais, Belo Horizonte, Brazil, bSchool of Pharmacy, Regis \\ University, Denver, Colorado, United States of America \\ Email: simoneamm@gmail.com
}

Received: 20 Nov 2016 Revised and Accepted: 29 Dec 2016

\begin{abstract}
Objective: To identify studies describing and/or assessing pharmacy practice experiential programs focusing on clinical education.

Methods: A systematic literature review was carried out. The databases searched included Lilacs, Medline/Pubmed, Eric and Scopus. The search strategy was devised based on a combination of subject headings related to pharmacy practice experiential programs, pharmacy education, and clinical practice in pharmacy. Two reviewers independently performed article selection, applying eligibility criteria defined. The level of agreement between the reviewers (Kappa coefficient) was calculated. Information about the clinical practice and settings used, description of pharmacy practice experiential model and type of evaluation study performed was collected from the articles selected using a pre structured form.

Results: Of the 474 items retrieved in the initial search, 31 articles met the eligibility criteria. An increase in the number of publications in the 2000 s was noted, predominantly $(\mathrm{n}=22,71.0 \%)$ from North America. Pharmaceutical care was the most commonly used term to denote clinical practice in pharmacy. The practice sites ranged from hospitals $(n=13,41.9 \%)$, outpatient clinics $(n=12,38.7 \%)$, community pharmacies $(n=7$, $22.6 \%)$ and other community institutions ( $\mathrm{n}=10,32.3 \%)$, whereas some experiences involved a combination of these settings. The most common organizational arrangement involved pharmacists from the healthcare service as preceptors supervising students in the field, and teachers as educators, tutors and researchers within universities. In some situations, however, teachers and more advanced students acted as preceptors. Educational outcomes and/or results related to the service delivered by students and preceptors were assessed, where the quantitative method was the most frequently employed approach in both cases.
\end{abstract}

Conclusion: The studies revealed that the partnership among university, health services and community is a promising initiative for improving the quality of pharmaceutical services offered to society and of pharmaceutical education.

Keywords: Pharmacy practice experience, Pharmaceutical care, Systematic literature review

(C) 2016 The Authors. Published by Innovare Academic Sciences Pvt Ltd. This is an open access article under the CC BY license (http://creativecommons.org/licenses/by/4. 0/) DOI: http://dx.doi.org/10.22159/ijpps.2017v9i2.16247

\section{INTRODUCTION}

Worldwide, albeit at different times and pace, the pharmacy profession is being redesigned according to an approach underpinned by patient-centered care and the achievement of patients' drug therapy needs at different levels of healthcare [1-4]. Pharmaceutical care-based services have shown positive clinical, economic and humanistic results, justifying their expansion and consolidation within healthcare systems [5-14].

The challenge of changes in the practice calls for and drives changes in education $[15,16]$. Guidelines and recommendations on a new model for degree courses in pharmacy have guided many experiences of innovation in pharmaceutical education [14-18]. These documents define practice experiences as essential components for developing the competencies necessary for clinical practice of pharmacists. This educational strategy facilitates the training of professionals engaged with social health needs. This brings universities and healthcare services closer together, enhancing the potential contribution of the two institutions to society.

It is important for teachers and managers of educational institutions to regularly update pharmacy degree curricula and incorporate pedagogic innovations that further contribute to improving the clinical education of students $[16,17]$. Keeping abreast of advances in the scientific literature regarding pedagogic innovations involving clinical education in pharmacy is a first step in this process. Knowledge of successful experiences allows their subsequent adaptation to the local context for implementation and assessment $[18,19]$.

Therefore, in light of educational recommendations emphasizing the importance of practical experiences in the education of pharmacists, the aim of this systematic review was to identify and describe pharmacy practice experiential programs focusing on clinical education.

\section{MATERIALS AND METHODS}

The method employed was a systematic literature review, according to the criteria recommended by Moher et al. [20] in the document Preferred reporting items for systematic review and meta-analysis protocols (PRISMA-P) 2015 statement. The criteria, as applied to the present study, are outlined below:

\section{Search strategy}

This was devised based on the definition of key words, identification of corresponding headings (MeSH/DeCs; English, Portuguese and Spanish) and application of Boolean operators and quotation marks for compound terms. No filters were applied.

\section{Information sources}

The Eric, Lilacs, Medline/Pubmed and Scopus databases were used. The search was conducted in June 2015.

\section{Organization of data}

The reference lists obtained from the different databases were pooled in the EndNote ${ }^{\circledR}$ references management program, available free to research institutions via the Capes Periodicals Portal (provided by the Brazilian government). Duplicate references were removed.

\section{Study selection}

Two reviewers independently performed article selection based on reading of: 1) titles; 2) abstracts; and 3) full articles. A form was 
used to record each stage, allowing the level of agreement (Kappa coefficient) between reviewers to be defined [21].

\section{Eligibility criteria}

Studies describing and/or assessing results of pharmacy practice experiential programs in the clinical area involving pharmacy degree students were included. The results extracted included the characteristics of the educational programs and type of evaluation conducted.

\section{Exclusion criteria}

Articles written in languages other than English, Portuguese or Spanish, articles not available via the Capes Periodicals Portal or not free of charge were excluded. Official documents (guidelines, guides and educational recommendations), reviews, editorials and comments were also excluded.

\section{Data collection}

General data was collected (year of publication, journal and country of origin), along with specific data on the clinical practice and settings used, description of pharmacy practice experiential model and type of evaluation study performed.

\section{RESULTS}

The results obtained at each stage of the article selection process are depicted in fig. 1 . The 31 studies selected by both reviewers were included [22-52] and had a Kappa coefficient of 0.94, indicating excellent agreement [21].

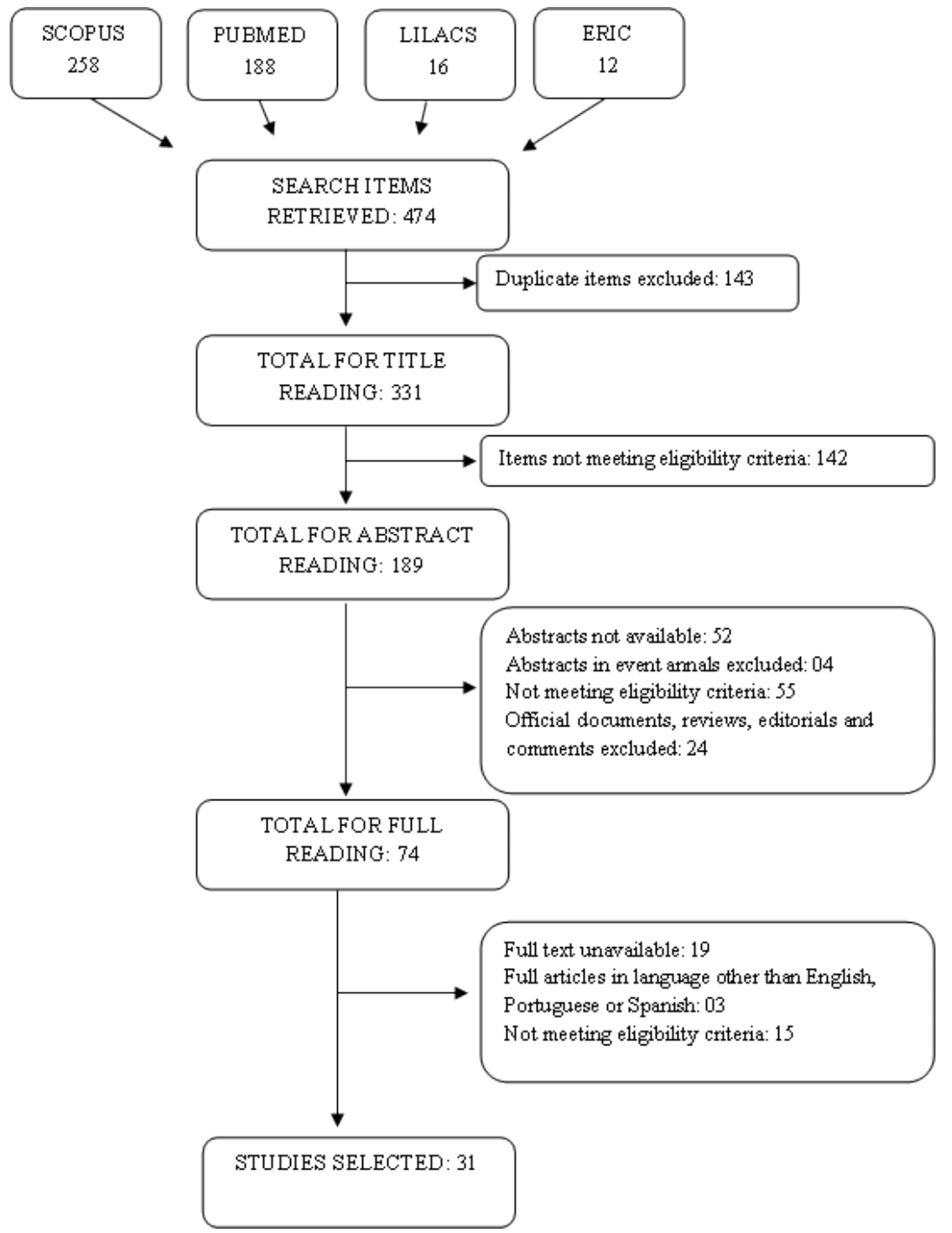

Fig. 1: Flow chart of article selection process

Four journals accounted for publication of $23(80.7 \%)$ of the total articles, with 17 articles (54.8\%) published in the American Journal of Pharmaceutical Education, four $(12.9 \%)$ in Currents in Pharmacy Teaching and Learning and two (6.5\%) in both Advances in Medical Education and Practice and International Journal of Pharmacy Practice. Most articles were from North America ( $\mathrm{n}=22,71.0 \%)$, comprising 19 (61.3\% of total) from the United States of America and three from Canada. The other publishing continents were: Europe $(n=3,9.7 \%)$ with articles from Germany and Denmark; Asia (n=2, 6.5\%) with contributions from Lebanon and Taiwan; Africa $(n=2,6.5 \%)$ with studies from Nigeria and Ethiopia; and Latin America and Oceania with Chile and Australia each contributing one article $(n=1,3.2 \%)$.

The articles retrieved were published between 1998 and 2015, with publication periods distributed as follows: one (3.2\%) in the 1990s, nine (29.0\%) between 2000 and 2009; and 21 (67.7\%) between 2010 and 2015. No restriction was placed on year of publication during the search process.

The most widely used term for specifying clinical practice resulting from the practice experiential programs was "pharmaceutical care". 
Thirteen articles (41.9\%) used this term without specifying its theoretical-methodological bases, four of which concerned different activities involving direct patient contact early in training with the aim of preparing students to subsequently deliver "pharmaceutical care practice". Three studies $(9.7 \%)$ made reference to "patientcentered care", an important characteristic of the professional philosophy of pharmaceutical care [3]. Others associated the term "pharmaceutical care" with specific services and activities, such as "medication therapy management" $(\mathrm{n}=7,22.6 \%)$, "medication review" $(\mathrm{n}=2,6.5 \%)$, "medication reconciliation" and "counseling", both with $n=1,3.2 \%$. It is noteworthy that the search strategy was made more sensitive by incorporating the clinical pharmacy and pharmaceutical care subject headings. In article selection, the researchers also included studies on any clinical pharmacy practice, given that relevant organizational arrangements or practice experiential program models could be developed despite the concept of professional practice adopted by the authors. The sites where the pharmacy practice experience took place encompassed different levels of healthcare, where some studies involved different practice settings concomitantly. The hospital environment predominated, being the site of 13 studies (41.9\%). Primary or secondary care outpatient clinics were the focus in 12 studies (38.7\%), although it was not possible to distinguish between these two different healthcare levels in many articles. Community pharmacies were the practice setting in seven articles $(22.6 \%)$. The healthcare network was the setting for 17 studies (54.8\%), whereas 03 studies (9.7\%) cited university-run services. Some studies were conducted at longterm care institutions or community centers for the elderly $(n=4$, $12.9 \%)$, as well as at other social/community institutions $(n=6$, $19.4 \%)$.

Regarding support of universities in the implementation and/or provision of the service where students undertake their learning, 19 articles $(61.3 \%)$ reported that students were responsible for providing clinical services not hitherto available, or for increasing the number of consultations/quality of the service delivered, both within the health system and in services provided directly to the community (university-run services or within community-based institutions). Four articles (12.9\%) cited the provision of formal processes of education to preceptors.

The main characteristics of the pharmacy practice experiences were reported in different ways in the articles and are summarized in table 1.

Table 1: Summary of characteristics of pharmacy practice experiences reported in articles selected

\begin{tabular}{|c|c|c|c|c|c|}
\hline \multirow{2}{*}{\multicolumn{2}{|c|}{$\begin{array}{l}\text { First author, year of publication } \\
\text { (country) }\end{array}$}} & \multicolumn{3}{|c|}{ Characteristics of pharmacy practice experiential programs } & \multirow{2}{*}{$\begin{array}{l}\text { Specificities of the } \\
\text { program described }\end{array}$} \\
\hline & & Partici- pants & Duration & Organizational arrangement & \\
\hline \multirow[t]{4}{*}{$\begin{array}{l}\text { Development } \\
\text { of the } \\
\text { preceptor } \\
\text { and the } \\
\text { practice } \\
\text { scenario }\end{array}$} & $\begin{array}{l}\text { Ackman et al., } 2011 \\
\text { (Canada) }\end{array}$ & $\begin{array}{l}\text { 4th year } \\
\text { pharmacy } \\
\text { students }\end{array}$ & $6 \mathrm{w}$ & $\begin{array}{l}122 \text { preceptors with students in the } \\
\text { field }\end{array}$ & $\begin{array}{l}\text { Virtual community of } \\
\text { practices for the } \\
\text { development of pharmacists } \\
\text { in pharmaceutical care and } \\
\text { as preceptors }\end{array}$ \\
\hline & $\begin{array}{l}\text { Kassam et al., } 2012 \\
\text { (Canada) }\end{array}$ & $a$ & $a$ & Preceptors with students in the field & $\begin{array}{l}\text { Online course for the } \\
\text { development of pharmacists } \\
\text { in pharmaceutical care and } \\
\text { as preceptors }\end{array}$ \\
\hline & $\begin{array}{l}\text { Kassam et al., } 2013 \\
\text { (Canada) }\end{array}$ & $\begin{array}{l}4 \text { th year } \\
\text { pharmacy } \\
\text { students }\end{array}$ & $8 w$ & $\begin{array}{l}\text { Preceptors with students in the field, } \\
\text { and faculty member at the university }\end{array}$ & $\begin{array}{l}\text { Preparatory course for } \\
\text { preceptors and students }\end{array}$ \\
\hline & $\begin{array}{l}\text { Sørensen et al., } 2008 \\
\text { (Denmark) }\end{array}$ & $a$ & $6 \mathrm{mo}$ & $\begin{array}{l}\text { Preceptors with students in the field, } \\
\text { and faculty member at the university }\end{array}$ & $\begin{array}{l}\text { Action research cycles for } \\
\text { the development of practice } \\
\text { scenarios (clinical pharmacy } \\
\text { services) }\end{array}$ \\
\hline \multirow[t]{7}{*}{$\begin{array}{l}\text { Preparatory } \\
\text { course for } \\
\text { practice } \\
\text { experience }\end{array}$} & $\begin{array}{l}\text { Galal et al., } 2012 \\
\text { (USA) }\end{array}$ & $\begin{array}{l}\text { 2nd year } \\
\text { pharmacy } \\
\text { students }\end{array}$ & $\begin{array}{l}2 \mathrm{w} \\
(15 \mathrm{~h})\end{array}$ & $\begin{array}{l}33 \text { students; } 4 \text { faculty members as } \\
\text { preceptors in the field; volunteer } \\
\text { community pharmacists preceptors in } \\
\text { the field }\end{array}$ & $\begin{array}{l}\text { Preparatory studies before } \\
\text { field activities ( } 10 \mathrm{w} \text { in class, } \\
3 \mathrm{~h} \text { /week) }\end{array}$ \\
\hline & $\begin{array}{l}\text { Galal et al., } 2014 \\
\text { (USA) }\end{array}$ & $\begin{array}{l}\text { 6th year } \\
\text { pharmacy } \\
\text { students }\end{array}$ & $1 \mathrm{y}$ & $\begin{array}{l}5 \text { faculty members e } 181 \text { students (for } \\
6 \text { y) }\end{array}$ & $\begin{array}{l}\text { Preparatory studies before } \\
\text { field activities }\end{array}$ \\
\hline & $\begin{array}{l}\text { Hasan et al., } 2013 \\
\text { (Australia) }\end{array}$ & $\begin{array}{l}4 \text { th year } \\
\text { pharmacy } \\
\text { students }\end{array}$ & $9 \mathrm{w}$ & $\begin{array}{l}\text { Preceptors with students in the field, } \\
\text { and faculty member at the university }\end{array}$ & $\begin{array}{l}\text { Previous experience in } \\
\text { providing clinical skills }\end{array}$ \\
\hline & $\begin{array}{l}\text { Johnson et al., } 2014 \\
\text { (USA) }\end{array}$ & $\begin{array}{l}\text { 1st and } 2 \text { nd } \\
\text { years pharmacy } \\
\text { students }\end{array}$ & $1 \mathrm{w}$ & $\begin{array}{l}08 \text { students in the field, } 1 \text { faculty } \\
\text { member at the university and in the } \\
\text { field }\end{array}$ & $\begin{array}{l}\text { Previous studies on the } \\
\text { main clinical condition of } \\
\text { patients treated at the } \\
\text { health service }\end{array}$ \\
\hline & $\begin{array}{l}\text { McGivney et al., } 2011 \\
\text { (USA) }\end{array}$ & $\begin{array}{l}\text { 1st and } 4 \text { th years } \\
\text { pharmacy } \\
\text { students }\end{array}$ & $2 \mathrm{mo}$ & $\begin{array}{l}\text { Groups of } 101^{\text {st }} \text { year pharmacy } \\
\text { students with a faculty member and } \\
\text { one or two } 4^{\text {th }} \text { year pharmacy } \\
\text { students in the field }\end{array}$ & $\begin{array}{l}\text { Preparatory course for the } \\
\text { field activity }\end{array}$ \\
\hline & $\begin{array}{l}\text { Schellhase et al., } 2013 \\
\text { (USA) }\end{array}$ & $a$ & $8 w$ & $\begin{array}{l}36 \text { students annually ( } 171 \text { students } \\
\text { since } 2004 \text { ); } 2 \text { faculty members at the } \\
\text { university; faculty members, clinical } \\
\text { pharmacists and residents in the field }\end{array}$ & $\begin{array}{l}\text { Preparatory course on } \\
\text { clinical activities and } \\
\text { cultural issues }\end{array}$ \\
\hline & $\begin{array}{l}\text { Schorr et al., } 2014 \\
\text { (Germany) }\end{array}$ & $a$ & $6 \mathrm{mo}$ & $\begin{array}{l}27 \text { students and } 7 \text { clinical pharmacists } \\
\text { as preceptors in the field, } 1 \text { monitor } \\
\text { who made bimonthly visits to the } \\
\text { fields of practice }\end{array}$ & $\begin{array}{l}\text { Two-day preparatory } \\
\text { training for students and } \\
\text { preceptors }\end{array}$ \\
\hline
\end{tabular}




\begin{tabular}{|c|c|c|c|c|c|}
\hline & $\begin{array}{l}\text { Skledar et al., } 2006 \\
\text { (USA) }\end{array}$ & $a$ & $\begin{array}{l}3 \text { y (full- } \\
\text { time on } \\
\text { vacations } \\
\text { and } 10-12 \\
\text { h during } \\
\text { school } \\
\text { year) }\end{array}$ & $\begin{array}{l}24 \text { students (since } 1998 \text { ) with faculty } \\
\text { member and clinical pharmacist in the } \\
\text { field }\end{array}$ & $\begin{array}{l}\text { Training offered by the } \\
\text { faculty member, researchers } \\
\text { and clinical pharmacists } \\
\text { supporting the project }\end{array}$ \\
\hline & $\begin{array}{l}\text { VanTyle et al., } 2011 \\
\text { (USA) }\end{array}$ & $a$ & $1 \mathrm{mo}$ & $\begin{array}{l}23 \text { students with medical director as } \\
\text { preceptor }\end{array}$ & $\begin{array}{l}\text { Preparatory courses related } \\
\text { to the Mexican culture, } \\
\text { language and health for field } \\
\text { experience }\end{array}$ \\
\hline \multirow{8}{*}{$\begin{array}{l}\text { University } \\
\text { activities } \\
\text { concomitant } \\
\text { with } \\
\text { pharmacy } \\
\text { practice } \\
\text { experience }\end{array}$} & $\begin{array}{l}\text { Agness et al., } 2011 \\
\text { (USA) }\end{array}$ & $\begin{array}{l}\text { 3rd year } \\
\text { pharmacy } \\
\text { students }\end{array}$ & $1 \mathrm{y}$ & $\begin{array}{l}2 \text { faculty members at the university } \\
\text { and in the field for first appointment; } \\
01 \text { pharmacist in the selection of } \\
\text { patients; teams of } 2-3 \text { students for } \\
\text { each of the } 57 \text { patients }\end{array}$ & $\begin{array}{l}\text { Parallel to pharmacotherapy } \\
\text { courses }\end{array}$ \\
\hline & $\begin{array}{l}\text { Brown et al., } 2002 \\
\text { (USA) }\end{array}$ & $\begin{array}{l}\text { 1st, } 2 \text { nd and } 3 \text { rd } \\
\text { year pharmacy } \\
\text { students }\end{array}$ & $6 \mathrm{mo}$ & $\begin{array}{l}15 \text { faculty members; } 315 \text { students in } \\
86 \text { teams, each with one patient; } 10 \\
\text { preceptors (faculty members, } \\
\text { residents or other post-graduates } \\
\text { students) }\end{array}$ & $\begin{array}{l}\text { Parallel classes at the } \\
\text { university for orientation } \\
\text { and studies }\end{array}$ \\
\hline & $\begin{array}{l}\text { Kearney et al., } 2013 \\
\text { (USA) }\end{array}$ & $\begin{array}{l}\text { 1st year } \\
\text { pharmacy } \\
\text { students }\end{array}$ & $\begin{array}{l}10 \mathrm{w} \\
(2 \\
\mathrm{h} / \text { week })\end{array}$ & $\begin{array}{l}\text { Students in the field, faculty members } \\
\text { at the university }\end{array}$ & $\begin{array}{l}\text { Weekly seminars parallel to } \\
\text { the experience }(1 \mathrm{~h} / \text { week })\end{array}$ \\
\hline & $\begin{array}{l}\text { Nichols-English et al., } \\
2002 \\
\text { (USA) }\end{array}$ & $\begin{array}{l}\text { 3rd year } \\
\text { pharmacy } \\
\text { students }\end{array}$ & $1 \mathrm{y}$ & $\begin{array}{l}2-5 \text { students in the field, teacher at the } \\
\text { university }\end{array}$ & $\begin{array}{l}\text { Preparatory course ( } 15 \text { wly } \\
\text { classes) and classes parallel } \\
\text { to field activities }\end{array}$ \\
\hline & $\begin{array}{l}\text { Ruiz et al., } 2002 \\
\text { (Chile) }\end{array}$ & $\begin{array}{l}\text { Final year } \\
\text { pharmacy } \\
\text { students }\end{array}$ & $\begin{array}{l}12 \mathrm{w} / 210 \\
\mathrm{~h}\end{array}$ & $\begin{array}{l}\text { Students in the field with preceptors } \\
\text { and faculty members at the university }\end{array}$ & $\begin{array}{l}\text { Classroom discussions and } \\
\text { presentation at end of } \\
\text { experience }\end{array}$ \\
\hline & $\begin{array}{l}\text { Ubaka et al., } 2012 \\
\text { (Nigeria) }\end{array}$ & $\begin{array}{l}\text { Final year } \\
\text { pharmacy } \\
\text { students }\end{array}$ & $8 w$ & $\begin{array}{l}\text { Students in the field with preceptors } \\
\text { and faculty members at the university }\end{array}$ & $\begin{array}{l}4 \mathrm{w} \text { of classroom } \\
\text { discussions, parallel to field } \\
\text { activities }\end{array}$ \\
\hline & $\begin{array}{l}\text { Walker et al., } 2010 \\
\text { (USA) }\end{array}$ & $\begin{array}{l}\text { 4th year } \\
\text { pharmacy } \\
\text { students }\end{array}$ & $4 \mathrm{w}$ & Students in the field with preceptors & $\begin{array}{l}\text { 5-hour weekly meetings for } \\
\text { discussions with preceptor }\end{array}$ \\
\hline & $\begin{array}{l}\text { Yeh et al., } 2014 \\
\text { (Taiwan) }\end{array}$ & $\begin{array}{l}\text { 4th year } \\
\text { pharmacy } \\
\text { students }\end{array}$ & $\begin{array}{l}4 \mathrm{w} \\
(40 \\
\text { h/week) }\end{array}$ & $\begin{array}{l}\text { Students in the field with preceptors } \\
\text { and faculty members at the university }\end{array}$ & $\begin{array}{l}\text { Software for eLearning to } \\
\text { support activities in the } \\
\text { field, substituting face-to- } \\
\text { face activities }\end{array}$ \\
\hline \multirow[t]{9}{*}{ Other } & $\begin{array}{l}\text { Dalal et al., } 2010 \\
\text { (USA) }\end{array}$ & $\begin{array}{l}\text { 3rd and } 4 \text { th } \\
\text { years pharmacy } \\
\text { students }\end{array}$ & $6 \mathrm{w}$ & $\begin{array}{l}\text { Students with pharmacists preceptors } \\
\text { in the field }\end{array}$ & $a$ \\
\hline & Dy et al., 2013 (USA) & $a$ & $a$ & $\begin{array}{l}\text { Students with volunteer pharmacists } \\
\text { as preceptors; a faculty member } \\
\text { assists students in the organization of } \\
\text { activities }\end{array}$ & $a$ \\
\hline & $\begin{array}{l}\text { Gerdemann et al., } 2007 \\
\text { (Germany) }\end{array}$ & $a$ & $\begin{array}{l}36 \text { mo } \\
\text { (6 mo per } \\
\text { student, } \\
\text { comprisin } \\
\text { g } 3 \text { mo of } \\
\text { clinical } \\
\text { activities) }\end{array}$ & $\begin{array}{l}17 \text { students in } 6 \text { different hospitals } \\
\text { accompanying doctors and nurses and } \\
\text { supervised by a pharmacist. One } \\
\text { faculty researcher was in the field } \\
\text { with each student twice during the } \\
\text { study period }\end{array}$ & $a$ \\
\hline & $\begin{array}{l}\text { Meierhofer et al., } 2013 \\
\text { (USA) }\end{array}$ & $a$ & $14 \mathrm{mo}$ & $\begin{array}{l}36 \text { students for different periods in } \\
\text { the field; } 1 \text { faculty member at } \\
\text { university; } 3 \text { pharmacists as } \\
\text { preceptors ( } 2 \text { faculty member and } 1 \\
\text { resident) }\end{array}$ & $a$ \\
\hline & $\begin{array}{l}\text { Roche et al., } 2007 \\
\text { (USA) }\end{array}$ & $a$ & $\begin{array}{l}\text { Not } \\
\text { described }\end{array}$ & $\begin{array}{l}15 \text { students and } 1 \text { pharmacist as } \\
\text { preceptor }\end{array}$ & $a$ \\
\hline & $\begin{array}{l}\text { Schumann et al., } 2004 \\
\text { (USA) }\end{array}$ & $\begin{array}{l}1 \text { st, } 2 \text { nd and } 4 \text { th } \\
\text { year pharmacy } \\
\text { students }\end{array}$ & $\begin{array}{l}\text { 6-8 w (2 } \\
\text { h/week) }\end{array}$ & $\begin{array}{l}50 \text { pharmacy students and students } \\
\text { from other courses; } 1 \text { pharmacist } \\
\text { teacher and } 1 \text { social work teacher }\end{array}$ & $a$ \\
\hline & $\begin{array}{l}\text { Tsega et al., } 2015 \\
\text { (Ethiopia) }\end{array}$ & $\begin{array}{l}\text { 5th year } \\
\text { pharmacy } \\
\text { students }\end{array}$ & $1 \mathrm{y}$ & $\begin{array}{l}69 \text { students with supervision by } \\
\text { different preceptors in the various } \\
\text { practice venues (rotation between } 09 \\
\text { sites) }\end{array}$ & $a$ \\
\hline & $\begin{array}{l}\text { Turner et al., } 2007 \\
\text { (USA) }\end{array}$ & $a$ & $6 \mathrm{w}$ & $\begin{array}{l}\text { Teams of } 8 \text { students with a preceptor } \\
\text { in the field }\end{array}$ & $a$ \\
\hline & $\begin{array}{l}\text { Vrahnos et al., } 1998 \\
\text { (USA) }\end{array}$ & $\begin{array}{l}\text { 1st and } 2 \text { nd year } \\
\text { pharmacy } \\
\text { students }\end{array}$ & $\begin{array}{l}14 \mathrm{w}(6 \\
\mathrm{h} / \text { week })\end{array}$ & $\begin{array}{l}\text { Students with faculty members as } \\
\text { preceptors and final year students } \\
\text { and/or resident as co-preceptor }\end{array}$ & $a$ \\
\hline
\end{tabular}




\begin{tabular}{llll}
\hline $\begin{array}{l}\text { Zeitoun } \text { et al., 2014 } \\
\text { (Lebanon) }\end{array}$ & $\begin{array}{l}\text { 1st year } \\
\text { pharmacy } \\
\text { students }\end{array}$ & $\begin{array}{l}4 \mathrm{w}(8 \\
\text { h/day })\end{array}$ & $\begin{array}{l}\text { Students with preceptors in the field, } \\
\text { faculties at the university and as } \\
\text { preceptors in the field }\end{array}$ \\
\hline
\end{tabular}

${ }^{a}$ Not described in the study.

Some studies cited activities within the university simultaneously with activities in the healthcare service, to increase reflective practice while supporting students in their practical activities. Service-learning and experiential learning were the two most-cited pedagogic approaches in the articles selected. With regard to organizational arrangement, a wide variety in both composition and proportion of the different participants involved was evident. In most studies, pharmacy students were directly supervised by pharmacists in healthcare services whereas faculty members oversaw activities within universities. However, there were some situations in which no preceptor was present in the field or where faculty members and more advanced students (final year of pharmacy degree or post-graduate students) took on the role of preceptor.

The pharmacy practice experiential programs addressed by the articles included in this review had been evaluated from different perspectives. Some articles used the method of experience report, describing the characteristics of the educational program in great detail. Nine articles (29.0\%) evaluated the impact of the clinical appointments provided by students and preceptors. Indicators studied included increases in the number of appointments, drug therapy problems identified, interventions performed, achievement of therapeutic goals, user satisfaction and acceptance by the healthcare team.

Educational outcomes were the focus of study in 27 articles (87.0\%), most of which employed the quantitative approach. The most used data collection methods were structured questionnaires for selfassessment of students on the development of competencies and the analysis of educational instruments (such as structured observation records produced by preceptors). Only 7 articles used a qualitative approach for assessing educational outcomes, revealing a gap in the literature on understanding of the subjective aspects involved in these experiences. Participant observation and interview methods were employed in the qualitative studies conducted, as well as analysis of students' reflective journals. Student perception on the development of competencies or achievement of learning objectives was the main topic investigated in two types of educational studies.

\section{DISCUSSION}

The emergence of publications in the 1990s, and the increase observed in the 2000s, may have been influenced by the concept of pharmaceutical care proposed by Hepler and Strand in 1990 [1] and the incorporation of this concept in the US educational recommendations during the 2000s [53]. These recommendations stipulate a requirement for practical experience in pharmaceutical education. Both these events took place in the United States of America, the country accounting for most of the publications included in this review. These results highlight the role of different social actors-academia, representative councils and institutions-in implementing changes to pharmaceutical education.

This study highlighted the tendency for use of the term pharmaceutical care to denote the clinical practice of pharmacists in the countries where the studies were conducted.

The predominance of hospitals as the practice setting reflects the challenge posed in reforms of health systems and teaching models, involving a shift from the biomedical and hospital-centric paradigm to the bio-psychosocial paradigm, based on primary healthcare $[54,55]$. In addition, the higher number of experiences in hospitals and outpatient clinics, relative to those run within community pharmacies, may be related to the perception of better integration of pharmaceutical care at sites where, traditionally, other professionals perform their clinical practice and provide patient care, unlike pharmacies that are culturally associated with dispensing medicines [56, 57].

The large proportion of studies in which universities promote partnerships with healthcare systems and communities, relative to the number of experiences within education institutions, reflects a tendency not only in pharmacy courses but in health courses in general: partnerships among community, healthcare system and university [58-60].

Some studies described direct benefits of the partnership for pharmacists and for the healthcare services. Furthermore, the presence of students, the role of preceptor and constant relationship with the university, give rise to lifelong learning in the everyday practice of the professionals, conferring great benefits to all those involved [61].

The presence of practice experiential programs for students in the first years of the pharmacy degree indicates recognition of the need for early exposure to the healthcare service, with gradual increase in direct patient care up to the end of the course $[35,62]$.

The connection between practice and theory present in some studies is known to potentiate learning, avoiding the unapprised performance of activities by students while furnishing them with a critical perspective on their practice [63].

The need for more advanced teachers or students to assume the role of preceptors of students within healthcare services might be related to the fact that clinical pharmacy services were still considered an innovation and had not been implemented in all healthcare services. It is assumed that the faculty member heads up the planning, provision and maintenance of the clinical service, with this function adding to the roles of educator and researcher. None of the articles explored this issue.

The studies investigating the impact of services delivered by students and preceptors are an important product of the university's partnership with the healthcare service. Such knowledge can be of benefit not only to the management of the clinical-pharmaceutical service, but may also help promote dialogue and negotiations with managers and users with a view to expanding the service within the healthcare system.

The knowledge produced by the educational studies are important to aid the replanning of the experience and also as input for other faculties and education institutions in their processes of planning, operating and assessing similar experiences.

\section{Limitations}

The limitation on languages in the article selection process resulted in the exclusion of two articles in German, two in French, and one in Japanese. In addition, the non-inclusion of the European database Embase as a research source (not available free) may have prevented access to further articles.

\section{CONCLUSION}

This systematic literature review led to the identification of many articles describing and/or assessing practice experiential programs for clinical education of pharmacists. The most commonly used term to denote this practice was "pharmaceutical care", and an increase in publications was noted in the 2000s with a large number of experiences on the North American continent.

The practice settings ranged from hospitals, outpatient clinics, community pharmacies and other community institutions. Partnerships among university, health services and the community predominated, with scant studies involving university-run services. A host of different organizational arrangements in the structuring of experiences was found, predominantly involving pharmacists from the health service acting as preceptors supervising students in the field, and faculties performing teaching and research activities related to the experience within universities.

Educational outcomes and/or results related to the service provided by students and preceptors were assessed. The quantitative 
approach was the most frequently employed method, entailing application of structured questionnaires among study participants before and after the pharmacy practice experience and data collection based on records of clinical services delivered by students and preceptors.

The studies revealed that the partnership among university, health services and community is a promising initiative for improving the quality of pharmaceutical services offered to society and for creating a conducive environment for training future pharmacists. The knowledge produced in this study can be of value to universities, health services and other sectors of society in the planning, operation, assessment and reorganization of educational processes in pharmacy.

\section{ACKNOWLEDGEMENT}

The doctoral scholarship of the main author was funded by the Brazilian Federal Agency for Support and Evaluation of UnderGraduate Education (Capes). The access to scientific journals and reference management software was made possible by the Capes Periodicals Portal maintained by the Brazilian government's Ministry of Education (MEC).

\section{CONFLICTS OF INTERESTS}

\section{Declared none}

\section{REFERENCES}

1. Hepler CD, Strand LM. Opportunities and responsibilities in pharmaceutical care. Am J Hosp Pharm 1990;47:533-43.

2. Wiedenmayer K, Summers RS, Mackie CA, Gous AGS, Everard M. Developing pharmacy practice: a focus on patient care. Geneva; 2006.

3. Cipolle RJ, Strand LM, Morley PC. Pharmaceutical care practice: the patient-centered approach to Medication Management Services. 3rd ed. New York: McGraw-Hill; 2012. p. 697.

4. Pk A, Adepu R. Drug-related problems: an overview of various classification systems. Asian J Pharm Clin Res 2014;7:7-10.

5. Isetts BJ, Schondelmeyer SW, Artz MB, Lenarz LA, Heaton AH, Wadd WB, et al. Clinical and economic outcomes of medication therapy management services: The Minnesota experience. J Am Pharm Assoc 2008;48:203-11.

6. Ramalho de Oliveira D, Brummel AR, Miller DB. Medication therapy management: $10 \mathrm{Y}$ of experience in a large integrated health care system. J Manag Care Pharm 2010;16:185-95.

7. Borges AP de S, Guidoni CM, Freitas 0 de, Pereira LRL. Economic evaluation of outpatients with type 2 diabetes mellitus assisted by a pharmaceutical care service. Arq Bras Endocrinol Metabol 2011;55:686-91.

8. Aguiar PM, Balisa-Rocha BJ, Brito G de C, da Silva WB, Machado M, Lyra DP. Pharmaceutical care in hypertensive patients: a systematic literature review. Res Soc Administrative Pharm 2012;8:383-96.

9. Brummel AR, Soliman AM, Carlson AM, Ramalho De Oliveira D. Optimal diabetes care outcomes following face-to-face medication therapy management services. Popul Health Manag 2012;1:1-7.

10. Isetts BJ, Brummel AR, Ramalho De Oliveira D, Moen DW. Managing drug-related morbidity and mortality in the patientcentered medical home. Med Care 2012;50:997-1001.

11. McInnis T, Strand L, Webb CE. Integrating comprehensive medication management to optimise patient outcomes. PatientCentered Primary Care Collaborative Resource Guide; 2012.

12. Ramalho de Oliveira D, Shoemaker SJ, Ekstrand M, Alves MR. Preventing and resolving drug therapy problems by understanding patients' medication experiences. J Am Pharm Assoc 2012;52:71-80.

13. Schultz H, Westberg SM, Ramalho De Oliveira D, Brummel A. Patient-perceived value of medication therapy management (MTM) services: a series of focus groups. Inov Pharm 2012;3:1-8.

14. Mourão AOM, Ferreira WR, Martins MAP, Reis AMM, Carrillo MRG, Guimarães AG, et al. Pharmaceutical care program for type 2 diabetes patients in Brazil: a randomised controlled trial. Int J Clin Pharm 2013;35:79-86.
15. Moreira De Souza W, Mesquita AR, Antoniolli AR, Pereira De Lyra Júnior D, Barros W, Silva D. Teaching in pharmaceutical care: a systematic review. Afr J Pharm Pharmacol 2015;9:333-46.

16. Veettil SK, Rajiah K. Use of simulation in pharmacy practice and implementation in undergraduate pharmacy curriculum in India. Int J Pharm Pharm Sci 2016;8:1-5.

17. Sasikumar N, Fathima MP, Roja MP. Role of thinking on teaching competency-pre-service teachers perspective. Innovare J Educ 2013;1:2-4.

18. Sasikumar N. Impact of active learning strategies to enhance student performance. Innovare J Educ 2014;2:2-4.

19. Mesquita AR, Souza WM, Boaventura TC, Barros IMC, Antoniolli $A R$, Silva WB, et al. The effect of active learning methodologies on the teaching of pharmaceutical care in a Brazilian pharmacy faculty. PLoS One 2015;10:1-16.

20. Moher D, Shamseer L, Clarke M, Ghersi D, Liberatî A, Petticrew M, et al. Preferred reporting items for systematic review and metaanalysis protocols (PRISMA-P) 2015 statement. Syst Rev 2015;4:1-9.

21. Viera AJ, Garrett JM. Understanding interobserver agreement: the kappa statistic. Fam Med 2005;37:360-3.

22. Ackman ML, Romanick M. Developing preceptors through virtual communities and networks: experiences from a pilot project. Can J Hosp Pharm 2011;64:405-11.

23. Agness CF, Huynh D, Brandt N. An introductory pharmacy practice experience based on a medication therapy management service model. Am J Pharm Educ 2011;75:1-8.

24. Brown MC, Lind PR, Sorensen TD. Early pharmacy education with community teachers (EPhECT): a longitudinal servicelearning experience. Am J Pharm Educ 2002;66:443-9.

25. Dalal K, McCall KL, Fike DS, Horton N, Allen A. Pharmacy students provide care comparable to pharmacists in an outpatient anticoagulation setting. Am J Pharm Educ 2010;74:1-4.

26. Dy EA, Trueg TD, Mulvaney JM, Williams KL. Service and education within a student-run pharmacy: an evaluation of the Butler University Community Outreach Pharmacy. Curr Pharm Teach Learn 2013;5:245-55.

27. Galal SM, Patel RA, Thai HK, Phou CM, Walberg MP, Woelfel JA, et al. Impact of an elective course on pharmacy students attitudes, beliefs, and competency regarding Medicare Part D. Am J Pharm Educ 2012;76:1-9.

28. Galal SM, Carr-Lopez SM, Gomez S, Candidate P, Duong V, Mizoshiri C, et al. A collaborative approach to combining service, teaching, and research. Am J Pharm Educ 2014;78:1-7.

29. Gerdemann A, Griese N, Schulz M. Pharmacy interns on the ward a pilot study. Pharm World Sci 2007;29:34-8.

30. Hasan SS, Wong PS, Ahmed SI, Chong DWK, Mai CW, Pook P, et al. Perceived impact of clinical placements on students' preparedness to provide patient-centered care in Malaysia. Curr Pharm Teaching Learning 2013;5:303-10.

31. Johnson JL, Crawford LD, LaRochelle JM. A summer diabetes camp as an interprofessional service-learning experience for early experiential pharmacy students. Curr Pharm Teaching Learning 2014;6:494-501.

32. Kassam R, Kwong M, Collins JB. Advances in medical education and practice an online module series to prepare pharmacists to facilitate student engagement in patient-centered care delivery: development and evaluation. J Adv Med Education Pract 2012;3:61-71.

33. Kassam R, Kwong M, Collins JB. Promoting direct patient care services at community pharmacies through advanced pharmacy practice experiences. Int $\mathrm{J}$ Pharm Pract 2013;21:368-77.

34. Kearney KR. Impact of a service-learning course on first-year pharmacy students' learning outcomes. Am J Pharm Educ 2013;77:1-7.

35. McGivney MS, Hall DL, Stoehr GP, Donegan TE. An introductory pharmacy practice experience providing pharmaceutical care to elderly patients. Am J Pharm Educ 2011;75:1-9.

36. Meierhofer J, Baumgartner L, Howard K, Lounsbery J, Reidt S, Moon J. Facilitating student pharmacist learning through the student-led development of a service-learning opportunity. Curr Pharm Teach Learn 2013;5:611-5. 
37. Nichols-English GJ, White CA, Brooks PJ. Bridging community based pharmacy outreach with service-learning principles. Am J Pharm Educ 2002;66:124-31.

38. Roche VF, Jones RM, Hinman CE, Seoldo N. A Service-learning elective in native American culture, health and professional practice. Am J Pharm Educ 2007;71:1-8.

39. Ruiz I, Jirón M, Pinilla E, Paulos C, Pezzani M, Rubio B, et al. Pharmaceutical care education at the university of chile. Am J Pharm Educ 2003;66:144-7.

40. Schellhase EM, Miller ML, Ogallo W, Pastakia SD. An elective pharmaceutical care course to prepare students for an advanced pharmacy practice experience in Kenya. Am J Pharm Educ 2013;77:1-8.

41. Schorr SG, Eickhoff C, Feldt S, Hohmann C, Schulz M. Exploring the potential impact of hospital ward-based pharmacy interns on drug safety. Pharmazie 2014;69:316-20.

42. Schumann W, Moxley DP, Vanderwill W. Integrating service and reflection in the professional development of pharmacy students. Am J Pharm Educ 2004;68:1-8.

43. Skledar SJ, Mckaveney TP, Ward CO, Culley CM, Ervin KC, Weber RJ. Advanced practice internship: experiential learning in a drug use and disease state management program. Am J Pharm Educ 2006;70:1-10.

44. Sørensen EW, Haugbølle LS. Using an action research process in pharmacy practice research-A cooperative project between the university and internship pharmacies. Res Soc Administrative Pharm 2008;4:384-401.

45. Tsega B, Srikanth Bhagavathula A, Ranjan Sarkar B, Melaku T, Shewamene Z. Dovepress impact of clerkship attachments on students' attitude toward pharmaceutical care in Ethiopia. Adv Med Educ Pract 2015;6:385-91.

46. Turner CJ, Ellis S, Giles J, Maffeo C, Hansen L, Saseen JJ, et al. A strategy to develop advanced pharmacy practice experiences. Am J Pharm Educ 2007;71:1-8.

47. Ubaka CM, Ekwunife OI, Adibe MO. Does the clinical clerkship course improve students' attitudes towards pharmaceutical care? Int J Pharm Pract 2012;20:272-4.

48. VanTyle WK, Kennedy G, Vance MA, Hancock B. A spanish language and culture initiative for a doctor of pharmacy curriculum. Am J Pharm Educ 2011;75:1-8.

49. Vrahnos D, Maddux MS. Introductory clinical clerkship during the first and second professional years: emphasis in clinical practice and writing. Am J Pharm Educ 1998;62:53-61.

50. Walker PC, Jones JNT, Mason NA. An advanced pharmacy practice experience in transitional care. Am J Pharm Educ 2010;74:1-6.

51. Yeh YT, Chen HY, Cheng KJ, Hou SA, Yen YH, Liu CT. Evaluating an online pharmaceutical education system for pharmacy interns in critical care settings. Comput Methods Programs Biomed 2014;113:682-9.

52. Zeitoun AA, El Zein HL, Zeineddine MM. Effect of pharmacy practice program on pharmacy student learning, satisfaction, and efficiency: assessment of introductory pharmacy practice course. J Pharm Pract 2014;27:89-100.

53. ACPE. Accreditation Standards and Key Elements for the Professional Program in Pharmacy Leading to the Doctor of Pharmacy Degree. Chicago; 2015.

54. WHO. The World Health Report 2008: Primary health care now more than ever. Geneva: World Health Organization; 2008.

55. Ceccim RB, Feuerwerker LCM. O Quadrilátero da Formação para a Área da Saúde: Ensino, Gestão, Atenção e Controle Social. Physis Rev Saúde Coletiva 2004;14:41-65.

56. Ramalho-de Oliveira D, Machuca M. La atención farmacéutica: un futuro profesional para América Latina. In: Núria Homedes; Antonio Ugalde (Org) La Farmacia, los farmacéuticos y el uso adecuado de medicamentos en América Latina. Buenos Aires: Lugar Editorial; 2011. p. 264.

57. Patel H, Adepu R, Sapthagiri R, Parthasarathi G. Drugs and therapeutic information service provided by clinical pharmacists for an improved patient care: An experience from a tertiary care teaching hospital. Asian J Pharm Clin Res 2015;8:175-8.

58. Kuabara CT de M, Sales PR de S, Marin MJS, Tonhom SF da R. Integrating teaching and health services: an integrative literature review. Rev Min Enferm 2014;18:195-201.

59. Pinheiro R, Ricardo BC, Araujo R de M. Ensino-trabalhocidadania: novas marcas ao ensinar integralidade no SUS. Rio de Janeiro: IMS/UERJ: CEPESC: ABRASCO; 2006. p. 156.

60. Bollela VR, Germani ACCG, Campos H de H, Amaral E. Communitybased education for health professions: Learning from the Brazilian Experience. Ribeirão Preto: FUNPEC-Editora; 2014. p. 334.

61. Albuquerque VS, Gomes AP, Rezende CHA de, Sampaio MX, Dias OV, Lugarinho RM. A Integração Ensino-serviço no Contexto dos Processos de Mudança na Formação Superior dos Profissionais da Saúde. Rev Bras Educ Med 2008;32:356-62.

62. McGivney MS. Building an advanced pharmacy practice experience (APPE) site for doctor of pharmacy students. Curr Pharm Teach Learn 2009;1:25-32.

63. Kolb DA. Experiential learning: experience as the source of learning and development. 2nd ed. New Jersey: Pearson Education, Inc; 2015. p. 390.

\section{How to cite this article}

- $\quad$ Simone de Araújo Medina Mendonça, Beatriz Leal Meireles, Erika Lourenço de Freitas, Djenane Ramalho de Oliveira. Pharmacy practices experiential programs in the context of clinical education. Int J Pharm Pharm Sci 2017;9(2):35-41. 